TITLE:

\title{
A new species of Orobdella (Hirudinida: Arhynchobdellida: Orobdellidae) from Primorye Territory, Russian Far East
}

$\operatorname{AUTHOR}(S)$ :

Nakano, Takafumi; Prozorova, Larisa

\section{CITATION:}

Nakano, Takafumi ... [et al]. A new species of Orobdella (Hirudinida: Arhynchobdellida: Orobdellidae) from Primorye Territory, Russian Far East. Journal of Natural History 2019, 53(5-6): 351-364

ISSUE DATE:

2019-04-23

URL:

http://hdl.handle.net/2433/241021

\section{RIGHT:}

This is an Accepted Manuscript of an article published by Taylor \& Francis in 'Journal of Natural History' on 2019, available online: https:/www.tandfonline.com/10.1080/00222933.2019.1593539; The full-text file will be made open to the public on 23 Apr 2020 in accordance with publisher's 'Terms and Conditions for Self-Archiving'.; この論文は出版社 版でありません。引用の際には出版社版をご確認ご利用ください。; This is not the published version. Please cite only the published version. 
1 A new species of Orobdella (Hirudinida: Arhynchobdellida: Orobdellidae) from

Primorye Territory, Russian Far East

3

4 Takafumi Nakano ${ }^{\mathrm{a}}$ and Larisa Prozorova ${ }^{\mathrm{b}}$

5

6 a Department of Zoology, Graduate School of Science, Kyoto University, Kyoto 606-8502

7 Japan

8 E-mail: nakano@zoo.zool.kyoto-u.ac.jp

$9 \quad{ }^{b}$ Federal Scientific Center of the East Asia Terrestrial Biodiversity, Far Eastern Branch

10 Russian Academy of Sciences, Vladivostok 690022, Russia

E-mail: lprozorova@mail.ru

CONTACT Takafumi Nakano nakano@zoo.zool.kyoto-u.ac.jp

\section{Acknowledgements}

We are grateful to Mr. Vladimir Chistyakov for his assistance in our field survey. The authors

History, Smithsonian Institution) for their constructive comments on this manuscript. 
Disclosure statement

23 No potential conflict of interest was reported by the authors

\section{Funding} JP17K20064.

\section{Geolocation information}

KUZ Z2068, Z2070 (point): $43.129645^{\circ} \mathrm{N}, 132.798943^{\circ} \mathrm{E}$

KUZ Z2069 (point): $43.129113^{\circ} \mathrm{N}, 132.798925^{\circ} \mathrm{E}$

\section{ORCID}




\section{ABSTRACT}

A quadrannulate leech species, Orobdella ghilarovi sp. nov., from Primorye Territory in the southern Russian Far East is described. Phylogenetic analyses using nuclear 18S rRNA, 28S rRNA, histone H3, mitochondrial cytochrome $c$ oxidase subunit I, tRNA ${ }^{\text {Cys }}$, tRNA ${ }^{\text {Met }}$, 12S rRNA, tRNA ${ }^{\text {Val }}$, 16S rRNA, tRNA ${ }^{\text {Leu }}$ and NADH dehydrogenase subunit 1 markers showed that O. ghilarovi formed a fully supported clade with a monophyletic lineage comprising two species: O. kawakatsuorum and O. koikei, inhabiting Hokkaido, Japan. Quadrannulate Orobdella leeches distributed in the southern Primorye Territory have been identified as $O$. whitmani, which was originally described in Japan; these past records should be amended based on the taxonomic conclusions of this study.

http://zoobank.org/urn:lsid:zoobank.org:pub:8D91AC1C-5868-4F0B-A09D-423F7B50206C

\section{KEYWORDS}

Erpobdelliformes; terrestrial; macrophagous; molecular phylogeny; misidentification

\section{Introduction}


The genus Orobdella Oka, 1895 is an erpobdelliform leech taxon of the terrestrial macrophagous species inhabiting Far East Asia (Sawyer 1986; Oceguera-Figueroa et al. 2011; Nakano et al. 2012). Orobdella leeches are characterised by their mid-body somite annulation that can be grouped into three types, i.e. 4- (quadr-), 6- (sex-), and 8- (oct-) annulate, and their possession of the gastroporal duct in their digestive tract that receives a spermatophore during copulation (Nakano 2017a, 2017b). They can be also grouped into three morpho-types according to the body length of mature individuals, i.e. small, middle, and large-types (Nakano 2017a).

This genus now consists of 20 species: most of them, i.e. 17 species, are distributed in the Japanese Archipelago (Nakano 2017a, 2017b, 2018); one species was recorded in the Korean Peninsula and adjacent islets including Tsushima Island, and two species were described in Taiwan (Nakano and Lai 2012, 2017). Until the 1960s, however, the genus Orobdella comprised only three species described in Japan: the quadrannulate O. whitmani Oka, 1895, the sexannulate $O$. ijimai Oka, 1895, and the octannulate O. octonaria Oka, 1895. In the late 1960s, quadrannulate Orobdella individuals were recorded around Vladivostok City in Primorye Territory, Russian Far East, and they were identified as O. whitmani (Ghilarov et al. 1969). Although their identification in the Russian Far East Orobdella was followed by subsequent works (Ghilarov and Perel 1971; Lukin 1976; Kurcheva 1977), it was also 
75

suggested that the Russian quadrannulate Orobdella might be an undescribed species rather

than O. whitmani (Nakano 2012).

Quadrannulate Orobdella leeches were newly collected from near Vladivostok. In line with the results of the morphological examination and molecular phylogenetic analyses of the newly obtained specimens, they are described as a new species herein.

\section{Material and methods}

\section{Sampling and morphological examination}

Leeches were collected from a locality in Anisimovka, Primorye Territory, southern Russian

Far East. When possible, elevation and geographical coordinates for the collection site were obtained using a Garmin eTrex ${ }^{\circledR}$ GPS unit.

Specimens were relaxed by the gradual addition of absolute ethanol (EtOH) to freshwater, and then fixed in absolute EtOH. For DNA extraction, botryoidal tissue was removed from the posterior part around the caudal sucker of every specimen, and then preserved in absolute EtOH. The reminder of the body was fixed in 10\% formalin and preserved in 70\% EtOH. Four measurements were taken: body length (BL) from the anterior margin of the oral sucker to the posterior margin of the caudal sucker, maximum body width (BW), caudal sucker length (CL) from the anterior to the posterior margin of the sucker, and caudal sucker width (CW) from the right to the left margin of the sucker. Examination, 
dissection, and drawing of the specimens were conducted using a stereoscopic microscope with a drawing tube (Leica M125; Leica Microsystems, Wetzlar, Germany). Specimens used in this study were deposited in the Zoological Collection of Kyoto University (KUZ).

The numbering convention is based on Moore (1927): body somites are denoted by Roman numerals, and the annuli in each somite are given alphanumeric designations.

\section{Molecular phylogenetic analyses}

The phylogenetic position of the new Orobdella species within the genus was determined based on three nuclear and three mitochondrial markers: 1) 18S rRNA, 2) 28S rRNA, 3) histone H3, 4) cytochrome $c$ oxidase subunit I (COI), 5) tRNA ${ }^{\text {Cys }}$, tRNA ${ }^{\text {Met }}, 12 S$ rRNA, tRNA $^{\mathrm{Val}}$ and 16S rRNA (tRNA ${ }^{\text {Cys }}-16 \mathrm{~S}$ ), and 6) tRNA ${ }^{\text {Leu }}$ and NADH dehydrogenase subunit 1 (tRNA $\left.{ }^{\text {Leu}}-N D 1\right)$. Methods for the genomic DNA extraction, PCR and cycle sequencing reactions were elucidated in Nakano and Lai (2016, 2017). In total, 14 sequences were newly obtained in this study and deposited with the International Nucleotide Sequence Database Collaboration (INSDC) through DNA Data Bank of Japan (Table 1).

According to the previous phylogenetic study (Nakano et al. 2018), eight OTUs were selected as the outgroup for the present phylogenetic analyses (Table 1). The alignments of H3 and COI were trivial, as no indels were observed. The sequences of the other markers were aligned using MAFFT v. 7.407 L-INS-i (Katoh and Standley 2013). The lengths of the 
113

114

115

116

117

118

119

120

121

122

123

124

125

126

127

128

129

130

131

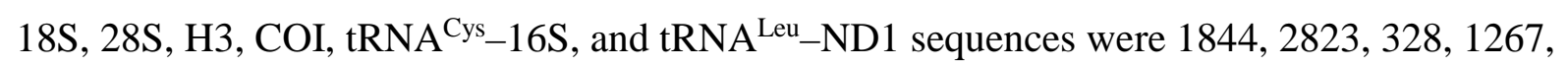

1182, and 640 bp, respectively. The concatenated sequences yielded 8084 bp of aligned

positions.

Phylogenetic trees were inferred using maximum likelihood (ML) and Bayesian inference (BI). The ML phylogeny was inferred using RAxML v. 8.2.8 (Stamatakis 2014) with the substitution model set as GTRCAT, immediately after nonparametric bootstrapping (BS) was conducted with 1000 replicates. The best-fit partition scheme was identified with the

Bayesian information criterion using PartitionFinder v. 2.1.1. (Lanfear et al. 2017) with the “greedy” algorithm (Lanfear et al. 2012): 18S, plus H3 1st and 2nd positions/28S/H3 3rd position/COI 1st position/each COI and ND1 2nd position/each COI and ND1 3rd position/tRNA ${ }^{\text {Cys }}$, tRNA ${ }^{\text {Met }}, 12 \mathrm{~S}$ and tRNA ${ }^{\text {Val }}$, tRNA ${ }^{\text {Leu }}$ and ND1 1st position/16S. BI and Bayesian posterior probabilities (PPs) were estimated using MrBayes v. 3.2.6 (Ronquist et al. 2012). The best-fit partition scheme and models for each partition were selected with the Bayesian information criterion using PartitionFinder with the "greedy" algorithm: for 18S and H3 1st position, K80+I+G; GTR+I+G for 28S; JC+I for H3 2nd position; HKY+G for H3 3rd position; GTR+G for COI 1st position; GTR+I+G for 2nd positions of COI and ND1; $\mathrm{HKY}+\mathrm{I}+\mathrm{G}$ for 3rd positions of COI and ND1; GTR+I+G for tRNA ${ }^{\text {Cys }-t R N A}{ }^{\text {Val }}$ and ND1 1st position; and GTR+G for 16S. Two independent runs of four Markov chains were conducted for 20 million generations, and the tree was sampled every 100 generations. The parameter 
132 estimates and convergence were checked using Tracer v. 1.7.1 (Rambaut et al. 2018), and the

133 first 50001 trees were discarded based on the results. 16S (1032 bp of aligned positions), and tRNA ${ }^{\text {Leu }}-\mathrm{ND} 1$ (630 bp) sequences obtained from the newly identified Orobdella were calculated using MEGA7.0.16 (Kumar et al. 2016). Prior to the calculation, tRNA ${ }^{\text {Cys }}$-16S sequences were aligned using MAFFT FFT-NS-2.

Type material

149 Holotype. KUZ Z2068 (Figure 1), dissected, collected from under a stone along a forest 
151 Territory, Russia, by Takafumi Nakano, on 21 August 2018.

Paratypes. In total 2 individuals collected from around the type locality on 21 August 2018:

154

155

156

157

158

159

160

161

162

163

164

165

166

167

168

169

KUZ Z2069 (43.129113ºN, 132.798925E; elev. 435 m) by Takafumi Nakano, and KUZ

Z2070 (43.129645N, 132.798943ํㄹ; elev. 435 m) by Larisa Prozorova.

\section{Diagnosis}

Body length of mature individual exceeding $60 \mathrm{~mm}$ (67.2 $\mathrm{mm}$ in maximum length). Somite IV uniannulate, somites VIII-XXV quadrannulate. Clitellum in somite XI b5 to somite XIII a2. Male gonopore in middle of somite XI b6, female gonopore in middle of somite XIII a1, behind gastropore, gonopores separated by $1 / 2+4+1 / 2$ annuli. Pharynx reaching to somite XIII/XIV. Gastropore conspicuous, in middle of somite XIII a1. Gastroporal duct bulbous. Paired epididymides in somites XVI-XIX, occupying 10 annuli. Atrial cornua developed, ovate.

\section{Description}

Body firm and muscular, elongate, with constant width in caudal direction, dorsoventrally compressed, BL 67.2 mm, BW 5.2 mm (Figure 1(a), 1(b)). Caudal sucker ventral, elliptic, CL 2.8 mm, CW 3.2 mm (Figures 1(b), 2(d)). 
Somite I completely merged with prostomium (Figure 2(a)). Somites II (= peristomium),

171 III and IV uniannulate (Figure 2(a)). Somite V biannulate, (a1 + a2) = a3; a3 forming

172 posterior margin of oral sucker (Figure 2(a), 2(b)). Somites VI and VII triannulate, a1 = a2 =

173 a3 (Figure 2(a), 2(b)). Somites VIII-XXV quadrannulate, a1 = a2 = b5 = b6 (Figure 2(a-e)).

174 Somite XXVI triannulate, a1 > a2 < a3 (b5 = b6 dorsally); a3 being ventrally last complete

175 annulus (Figure 2(c), 2(d)). Somite XXVII uniannulate with slight dorsolateral furrow on

176 respective sides (Figure 2(c)). Anus behind somite XXVII; post-anal annulus absent (Figure

$177 \quad 2(c))$.

178

Somite X b5 and somite XIII a2, respectively, being first and last annuli of clitellum

179 (Figure 2(e)).

180

Male gonopore in middle of somite XI b6 (Figure 2(e)). Female gonopore in middle of

somite XIII a1, inconspicuous, located posterior to gastropore (Figure 2(e), 2(f)). Gonopores

separated by $1 / 2+4+1 / 2$ annuli (Figure 2(e))

Anterior ganglionic mass in somite VI a2, a3 and somite VII a1. Ganglion VII in a2.

Ganglion VIII in a2 and b5. Ganglia IX-XII, of each somite, in a2 (Figure 3(c)). Ganglion

XIII in a2 and b5 (Figure 3(c)). Ganglia XIV-XXIV, of each somite, in a2 (Figure 3(c)).

Ganglion XXV in a1. Ganglion XXVI in somite XXV b6. Posterior ganglionic mass in somite

Eyes in 3 pairs, 1st pair dorsally on somite II/III, 2nd and 3rd pairs dorsolaterally on 
189

190

191

192

193

194

195

196

197

198

199

200

201

202

203

204

posterior margin of somite V (a1 + a2) (Figure 2(a)). Papillae numerous, minute, hardly visible, one row on every annulus.

Nephridiopores in 17 pairs, each situated ventrally at posterior margin of a1 of each somite in somites VIII-XXIV (Figure 2(b), 2(d), 2(e)).

Pharynx agnathous, euthylaematous, reaching to somite XIII/XIV (Figure 3(a)). Crop tubular, acaecate, reaching to somite XIX b5/b6 (Figure 3(b)). Intestine tubular, reaching to somite XXIII b5, with 1 pair of pouch-shaped intestinal caeca in somite XIX a2-b6 (Figure 3(b)); each caecum opening in behind junction between crop and intestine in somite XIX b6, then ascending to somite XIX a2. Rectum tubular, thin-walled, straight. Gastropore conspicuous, ventral, on middle of somite XIII a1 (Figure 2(e), 2(f)). Gastroporal duct bulbous, winding at junction with gastropore, reaching to somite XIII b6 (Figure 3(a)). Testisacs multiple; on right side, in somite XIX b5 to smite XXV a2, in total 28 testisacs, 1 in XIX, 5 in XX, 4 in XXI, 6 in XXII, 5 in XXIII, 5 in XXIV, 2 in XXV; on left side, in somite XIX b6 to somite XXV b5, in total 30 testisacs, 1 in XIX, 5 in XX, 5 in XXI, 6 in XXII, 5 in XXIII, 5 in XXIV, 3 in XXV. Paired epididymides in somite XVI b6 to somite XIX a1, occupying 10 annuli (Figure 3(c)). Paired ejaculatory duct in somite XI b5 to somite XVI b6 (Figure 3(c)); coiled in position posterior to ovisacs; each duct crossing ventrally beneath each ovisac, then nearly straight in position anterior to ovisacs; each widening from respective junction with epididymis, narrowing at junction with atrial cornua, then turning 
proximally toward atrial cornua without pre-atrial loop (Figure 3(c-f)). Pair of muscular atrial cornua developed, ovate, in somite XI b5 and b6 (Figure 3(c-f)). Atrium short, muscular, globular in somite XI b5 and b6 (Figure 3(d-f)). Penis sheath and penis absent.

213 into common oviduct in somite XIII a1/a2. Common oviduct thin-walled, short, directly

214 descending to female gonopore (Figure 3(g)).

\section{Variation}

217 Measurements ( $n=2$, paratypes only): BL 35.0-36.1 mm, BW 3.1 mm, CL 1.5-1.6 mm, CW

218 1.9-2.1 mm. Somite XXVI biannulate, a1 < (a2 + a3), (a2 + a3) with slight dorsolateral

219 furrow on respective sides, or triannulate a1 $>$ a2 $=$ a3. Small unpaired eye dorsally on right posterior margin of somite IV (KUZ Z2069).

\section{Colouration}

223 In life, dorsal surface yellow (Figure 1(c)), or yellowish brown; ventral surface whitish

224 yellow, or greyish white; clitellum, when obvious, paler than other body parts (Figure 1(c)).

225 Colour faded in preservative; dark mid-dorsal line present from somite VIII a1 to somite 


\section{Distribution}

According to the previous records of quadrannulate Orobdella leeches from around

Vladivostok (Ghilarov et al. 1969; Ghilarov and Perel 1971), O. ghilarovi inhabits the Ussuri

Nature Reserve in addition to the type locality.

\section{Natural history}

234 This species was found curled up under rocks in moist habitats along a forest road. Since a mature individual (= holotype) bearing a slight clitellum and developed testisacs as well as

236 ovisacs was collected on 21 August 2018, the reproductive season of this species may be

237 around August.

\section{Etymology}

240 The specific name is a noun in the genitive case formed directly from the name of the late $\mathrm{Dr}$

241 Merkuriy Sergeevich Ghilarov, who provided the first record of Orobdella leeches from

242 Primorye Territory (Ghilarov et al. 1969).

\section{Molecular analyses results}

245 The BI tree (mean $\ln L=-45227.02$; Figure 4) for determining the phylogenetic position of 
O. ghilarovi had an almost identical topology to that of the ML tree ( $\ln L=-46910.15$; not shown). Orobdella ghilarovi was a sister taxon of a well-supported clade (BS $=100 \%$, PP $=$ 1.0) including the two species, O. kawakatsuorum Richardson, 1975 and O. koikei Nakano, 2012, inhabiting Hokkaido, northern Japan, and adjacent islets (Nakano 2012; Nakano and supported $(\mathrm{BS}=100 \%, \mathrm{PP}=1.0)$. This clade was a sister lineage to a monophyletic group $(\mathrm{BS}=100 \%, \mathrm{PP}=1.0)$ consisting of the other 18 species known from the Korean Peninsula, Taiwan, and the other Japanese islands in the south of Hokkaido. This major monophyletic group was divided into two sub-lineages: a lineage corresponded to O. tsushimensis Nakano, 2011 that is distributed in the Korean Peninsula and adjacent islands; and another clade (BS = $77 \%, \mathrm{PP}=0.97)$ contained the remaining 17 species. exhibit any variations among them. Although base-compositions of the tRNA ${ }^{\text {Cys }}$-tRNA ${ }^{\text {Val }}$ regions in the three tRNA ${ }^{\text {Cys }}$-16S sequences (LC431616-LC431618) dovetailed completely

261 with each other, the remaining $16 \mathrm{~S}$ sequences were slightly variable, and thus the pairwise 
265 Orobdella ghilarovi clearly belongs to Orobdella as it possesses the generic diagnostic

266 features defined by Nakano (2016a). Its molecular phylogenetic position also supports the

267 present genus-level affinity of this new species. Additionally, the mitochondrial DNA

268 sequences obtained from the present three specimens fully supported their taxonomic identity

269 belonging to the same species. Although only one mature individual of the new species (=

270 holotype) could be obtained, the dissected holotype provided sufficient morphological

271 features of the new species along with the two undissected paratypes.

According to previous studies (Nakano 2010, 2011, 2012; Nakano and Lai 2012; Nakano

2018), therefore, the new species can be distinguished from the 12 quadrannulate congeners,

277 Nakano, 2014, O. meisai Nakano and Lai, 2017, O. naraharaetmagarum Nakano, 2016 b, O.

278 tsushimensis and $O$. whitmani, by the following combination of characteristics (Table 2):

279 middle-type body length, uniannulate somite IV, quadrannulate somite XXV, $1 / 2+4+1 / 2$

280 annuli between gonopores, pharynx reaching to posterior XIII, bulbous gastroporal duct,

281 epididymides in somites XVI-XIX that occupy 10 annuli, and developed ovate atrial cornua.

282 Orobdella ghilarovi is clearly distinguishable from the six sexannulate and two octannulate

283 species by its mid-body somites that are quadrannulate. 
were reported as O. whitmani, were not provided by Ghilarov et al. (1969), their precise

gonopores opened in the middle of the respective annuli, and the individuals possessed 4

annuli between the gonopores. This characteristic is coincident with the feature of $O$.

(Ghilarov et al. 1969), which is the old Chinese name of the type locality of the new species,

Ghilarov et al. (1969) and Ghilarov and Perel (1971) are judged herein as O. ghilarovi. 
kawakatsuorum and O. koikei, with insight into the biogeographical history of the genus

Orobdella. Future faunal and systematic studies of Orobdella leeches in the Russian Far East

including Sakhalin Island will lead us to a better understanding of the evolutionary and

biogeographical histories of this terrestrial macrophagous leech group. Moreover, a recent

molecular phylogenetic study shed light onto a distinctive phylogenetic status of the

American terrestrial macrophagous species Americobdella valdiviana (Philippi, 1872), and phylogroup within Erpobdelliformes (Nakano et al. 2012, 2018), future evolutionary studies taxa will elucidate a key evolutionary event of the arhynchobdellidan leeches.

\section{References}

Blanchard R. 1894. Hirudinées de l’Italie continentale et insulaire. Boll Mus Zool Anat Comp

Caballero ECy. 1953. Sanguijuelas de Mexico. XVIII. Presencia de Macrobdella decora (Say, 1824) Verrill, 1872, en el norte del pais, y nueva desinencia para los ordenes de Hirudinea. 
An Inst Biol Univ Mex. 27:203-209.

323

324

325

326

Ghilarov MS, Lukin EI, Perel TS. 1969. The first terrestrial leech-Orobdella whitmani Oka (Hirudinei, Herpobdellidae) — in the fauna of the USSR: A Tertiary relict of forests of the southern Maritime Territory. Dokl Akad Nauk SSSR. 188(1):235-237.

Ghilarov MS, Perel TS. 1971. Soil fauna in mixed coniferous-deciduous broadleaved forests of Southern Primorie (Soviet Far East). Pedobiologia. 11(3):240-261.

Katoh K, Standley DM. 2013. MAFFT multiple sequence alignment software version 7: improvements in performance and usability. Mol Biol Evol. 30(4):772-780.

Kumar S, Stecher G, Tamura K. 2016. MEGA7: Molecular Evolutionary Genetics Analysis Version 7.0 for bigger datasets. Mol Biol Evol. 33(7):1870-1874.

Kurcheva GF. 1977. Pochvennye bespozvonochnye sovetskogo Dal’nego Vostoka [Soil Invertebrates of the Soviet Far East]. Moscow: Nauka. Russian.

Lanfear R, Calcott B, Ho SYW, Guindon S. 2012. PartitionFinder: Combined selection of partitioning schemes and substitution models for phylogenetic analyses. Mol Biol Evol. 29(6):1695-1701.

Lanfear R, Frandsen PB, Wright AM, Senfeld T, Calcott B. 2017. PartitionFinder 2: New methods for selecting partitioned models of evolution for molecular and morphological phylogenetic analyses. Mol Biol Evol. 34(3):772-773.

Lukin EI. 1976. [Fauna USSR. Leeches]. Vol. 1. Leningrad: Nauka. Russian. 
Moore JP. 1927. The segmentation (metamerism and annulation) of the Hirudinea. In:

Harding WA, Moore JP. The Fauna of British India, including Ceylon and Burma

Hirudinea. London: Taylor \& Francis; p. 1-12.

Nakano T. 2010. A new species of the genus Orobdella (Hirudinida: Arhynchobdellida: the designation of the lectotype. Zool Sci. 27(11):880-887.

Nakano T. 2011. A new species of Orobdella (Hirudinida: Arhynchobdellida:

Gastrostomobdellidae) from Tsushima Island, Japan. Species Divers. 16(1-2):39-47.

Nakano T. 2012. A new species of Orobdella (Hirudinida, Arhynchobdellida, the phylogenetic position of the new species. ZooKeys. 169:9-30.

Nakano T. 2014. A new quadrannulate species of Orobdella (Hirudinida, Arhynchobdellida,

Nakano T. 2016b. A new quadrannulate species of Orobdella (Hirudinida, Arhynchobdellida, 
Japan. Tokyo: Springer Japan; p. 319-340.

361

362

363

364

365

366

367

Nakano T. 2017b. A new species of Orobdella (Hirudinida: Arhynchobdellida: Orobdellidae) from Japan reveals the function of the Orobdella gastroporal duct. Zool Sci. 34(2):161172.

Nakano T. 2018. A new quadrannulate species of Orobdella (Hirudinida: Arhynchobdellida: Orobdellidae) from Kii Peninsula, Japan. Species Divers. 23(1):43-49.

Nakano T, Eto K, Nishikawa K, Hossman MY, Jeratthitikul E. 2018. Systematic revision of the Southeast Asian macrophagous leeches, with the description of two new gastrostomobdellid species (Hirudinida: Arhynchobdellida: Erpobdelliformes). Zool J Linn Soc. $184(1): 1-30$.

Nakano T, Gongalsky KB. 2014. First record of Orobdella kawakatsuorum (Hirudinida: Arhynchobdellida: Erpobdelliformes) from Kunashir Island, Kuril Islands. Biodivers Data J. 2:e1058.

Nakano T, Lai Y-T. 2012. A new species of Orobdella (Hirudinida, Arhynchobdellida, Orobdellidae) from Taipei, Taiwan. ZooKeys. 207:49-63.

Nakano T, Lai Y-T. 2016. First record of Poecilobdella nanjingensis (Hirudinida: Arhynchobdellida: Hirudinidae) from Taiwan and its molecular phylogenetic position within the family. Species Divers. 21(2):127-134.

Nakano T, Lai Y-T. 2017. A new quadrannulate species of Orobdella (Hirudinida: 
Arhynchobdellida: Orobdellidae) from Pingtung, Taiwan. Species Divers. 22(2):143-150.

Nakano T, Ramlah Z, Hikida T. 2012. Phylogenetic position of gastrostomobdellid leeches

(Hirudinida, Arhynchobdellida, Erpobdelliformes) and a new family for the genus

Orobdella. Zool Scr. 41(2):177-185.

Nakano T, Seo H-Y. 2012. First record of Orobdella tsushimensis (Hirudinida:

Arhynchobdellida: Orobdellidae) from Korea (Gageodo Island) and its molecular

phylogenetic position within the genus. Species Divers. 17(2):235-240.

Nakano T, Seo H-Y. 2014. First record of Orobdella tsushimensis (Hirudinida: phylogenetic relationships of the specimens. Anim Syst Evol Divers. 30(2):87-94.

Oka A. 1895. On some new Japanese land leeches. (Orobdella nov. gen.). J Coll Sci Imp Univ Jpn. 8(2):275-306.

Philippi RA. 1872. Macrobdella, ein neues Geschlecht der Hirudineen. Z Ges Naturwiss N F. 6:439-442.

Rambaut A, Drummond AJ, Xie D, Baele G, Suchard MA. 2018. Posterior summarization in Bayesian phylogenetics using Tracer 1.7. Syst Biol. 67(5):901-904. 
398 Richardson LR. 1975. A new species of terricolous leeches in Japan (Gastrostomobdellidae, 399 Orobdella). Bull Natl Sci Mus Ser A (Zool). 1(1):39-56.

400 Ronquist F, Teslenko M, van der Mark P, Ayres DL, Darling A, Höhna S, Larget B, Liu L, 401 Suchard MA, Huelsenbeck JP. 2012. MrBayes 3.2: Efficient Bayesian phylogenetic 402 inference and model choice across a large model space. Syst Biol. 61(3):539-542.

403 Sawyer RT. 1986. Leech Biology and Behaviour. Oxford: Claredon Press.

404 Stamatakis A. 2014. RAxML version 8: a tool for phylogenetic analysis and post-analysis of 405 large phylogenies. Bioinformatics. 30(9):1312-1313.

406 Tessler M, de Carle D, Voiklis ML, Gresham OA, Neumann JS, Cios S, Siddall ME. 2018.

407 Worms that suck: Phylogenetic analysis of Hirudinea solidifies the position of 408 Acanthobdellida and necessitates the dissolution of Rhynchobdellida. Mol Phylogenet $409 \quad$ Evol. 127:129-134. 
411 Table 1. Samples used for phylogenetic analyses; the information on the vouchers is accompanied by the INSDC accession numbers

\begin{tabular}{|c|c|c|c|c|c|c|c|}
\hline \multirow{2}{*}{ Species } & \multirow{2}{*}{ Voucher $^{1}$} & \multicolumn{6}{|c|}{ INSDC\# $^{2}$} \\
\hline & & $18 \mathrm{~S}$ & $28 \mathrm{~S}$ & Histone H3 & COI & tRNA $^{\text {Cys }}-16 \mathrm{~S}$ & tRNA ${ }^{\text {Leu }}-\mathrm{ND} 1$ \\
\hline \multicolumn{8}{|l|}{ Orobdella } \\
\hline O. ghilarovi sp. nov. & KUZ Z2068 Holotype & LC431608* & LC431607* & LC431612* & LC431609* & LC431616* & LC431613* \\
\hline O. ghilarovi sp. nov. & KUZ Z2069 Paratype & & & & LC431610* & LC431617* & LC431614* \\
\hline O. ghilarovi sp. nov. & KUZ Z2070 Paratype & & & & LC431611* & LC431618* & LC431615* \\
\hline O. angustata & KUZ Z1439 Holotype & LC323140 & LC431606* & LC323138 & LC323139 & LC323141 & LC323137 \\
\hline O. brachyepididymis & KUZ Z1673 Holotype & LC106319 & LC274535 & LC106321 & LC106320 & LC106318 & LC106322 \\
\hline O. dolichopharynx & KUZ Z120 Holotype & AB663665 & LC274541 & AB698876 & AB679680 & AB679681 & AB828558 \\
\hline O. esulcata & KUZ Z29 Holotype & AB663655 & LC274538 & AB698873 & AB679664 & AB679665 & AB828555 \\
\hline O. ijimai & KUZ Z110 Topotype & AB663659 & LC274542 & AB698877 & AB679672 & AB679673 & AB828559 \\
\hline O. kanaekoikeae & KUZ Z1747 Holotype & LC184551 & LC274533 & LC184553 & LC184552 & LC184550 & LC184554 \\
\hline O. kawakatsuorum & KUZ Z167 Topotype & AB663661 & LC274544 & AB698878 & AB679704 & AB679705 & AB828561 \\
\hline O. ketagalan & KUZ Z208 Holotype & AB704785 & LC274546 & AB704786 & AB704787 & AB828582 & AB828563 \\
\hline O. koikei & KUZ Z156 Holotype & AB698883 & LC274543 & AB698882 & AB679688 & AB679689 & AB828560 \\
\hline O. masaakikuroiwai & KUZ Z694 Holotype & AB938003 & LC274530 & AB938013 & AB938006 & АВ937997 & АВ938016 \\
\hline O. meisai & KUZ Z1917 Holotype & LC314423 & LC431605* & LC314425 & LC314424 & LC314422 & LC314426 \\
\hline O. mononoke & KUZ Z224 Holotype & AB698868 & LC274547 & AB698869 & AB698866 & AB698867 & AB828564 \\
\hline O. nakahamai & KUZ Z1672 Holotype & LC106330 & LC274534 & LC106332 & LC106331 & LC106329 & LC106333 \\
\hline O. naraharaetmagarum & KUZ Z1652 Holotype & LC087143 & LC274531 & LC087145 & LC087144 & LC087142 & LC087146 \\
\hline O. octonaria & KUZ Z181 Topotype & AB698870 & LC274545 & AB698871 & AB679708 & AB679709 & AB828562 \\
\hline O. okanoi & KUZ Z1671 Holotype & LC106341 & LC274532 & LC106343 & LC106342 & LC106340 & LC106344 \\
\hline
\end{tabular}




\begin{tabular}{lccccccc}
$\begin{array}{l}\text { O. shimadae } \\
\text { O. tsushimensis }\end{array}$ & KUZ Z128 Holotype & AB663663 & LC274540 & AB698875 & AB679676 & AB679677 & AB828557 \\
O. whitmani & KUZ Z134 Holotype & AB663653 & LC274537 & AB698872 & AB679662 & AB679663 & AB828554 \\
O. yamaneae & KUZ Z45 Topotype & AB663657 & LC274539 & AB698874 & AB679668 & AB679669 & AB828556 \\
Outgroup & KUZ Z1678 Holotype & LC106349 & LC274536 & LC106351 & LC106350 & LC106348 & LC106352 \\
$\begin{array}{l}\text { Erpobdella japonica } \\
\text { Gastrostomobdella ampunganensis }\end{array}$ & ZRC.ANN.0083 Holotype & LC274517 & LC274516 & LC274552 & LC274551 & LC274564 & LC274571 \\
Gastrostomobdella extenta & MUMNH-Hir0001 Holotype & LC274519 & LC274518 & LC274554 & LC274553 & LC274565 & LC274572 \\
Gastrostomobdella monticola & UNIMAS/A3/BH01/10 & AB663649 & LC274515 & AB698880 & AB679656 & AB679657 & AB828543 \\
Gastrostomobdella cf. monticola & KUHE 56264 & LC274514 & LC274513 & LC274550 & LC274549 & LC274563 & LC274570 \\
Mimobdella japonica & KUZ Z179 & AB663650 & LC274528 & AB698881 & AB679658 & AB679659 & AB828544 \\
Odontobdella blanchardi & KUZ Z180 & AB663651 & LC274529 & AB938012 & AB938004 & AB937995 & AB938014 \\
Salifa motokawai & VNMN 2015.65 Holotype & LC029434 & LC274548 & LC029435 & LC029431 & LC029432 & LC029433 \\
\hline
\end{tabular}

${ }^{1}$ Acronyms: KUHE, Kyoto University, Human and Environmental Studies; KUZ, Zoological Collection of Kyoto University; MUMNH, Mahidol

413 University Museum of Natural History; UNIMAS, Universiti Malaysia Sabah; VNMN, Vietnam National Museum of Nature; ZRC, Zoological

414 Reference Collection, Lee Kong Chian Natural History Museum.

$415 \quad{ }^{2}$ Sequences marked with an asterisk $(*)$ were obtained for the first time in the present study. 
417 Table 2. Comparisons of morphological characters between Orobdella ghilarovi sp. nov. and 12 quadrannulate species

\begin{tabular}{|c|c|c|c|c|c|c|c|c|}
\hline Species & Body length & Somite IV & Somite XXV & Annuli between gonopores & Pharynx length & Gastroporal duct & Epididymides & Atrial cornua \\
\hline O. ghilarovi sp. nov. & middle & 1 & 4 & $1 / 2+4+1 / 2$ & to posterior XIII & bulbous & XVI to XIX & developed, ovate \\
\hline O. angustata & middle? & 1 & 4 & $1 / 2+4+1 / 3$ & to anterior XIV & bulbous & XVIII to XX & $\begin{array}{c}\text { developed, } \\
\text { hyperbologidal }\end{array}$ \\
\hline O. brachyepididymis & small & 1 & 4 & $1 / 2+4[+(<1 / 2)]$ & to anterior XIV & tubular & $\mathrm{XX}$ to $\mathrm{XXI}$ & small, ovate \\
\hline O. esulcata & middle & 1 & 4 & $2 / 3+4+1 / 3$ & to anterior to posterior XIV & $\begin{array}{l}\text { tubular, but bulbous at } \\
\text { junction with gastropore }\end{array}$ & $\mathrm{XVI}$ to $\mathrm{XX}$ & developed, ovate \\
\hline O. kanaekoikeae & small & 1 & 4 & $1 / 2+4+1 / 2$ & to posterior XIII to anterior XIV & bulbous & XIV to XVIII & developed, ovate \\
\hline O. kawakatsuorum & middle & 2 & 4 & 6 & to middle to posterior XIV & simple tubular & XVI to XVII & undeveloped \\
\hline O. ketagalan & middle & 1 & 4 & $1 / 2+4+1 / 2$ & to posterior XIV & simple tubular & absent & undeveloped \\
\hline O. koikei & small & 1 & 3 & $1 / 2+4+1 / 2$ & to posterior XIII to anterior XIV & bulbous & $\mathrm{XV}$ to $\mathrm{XX}$ & developed, ovate \\
\hline O. masaakikuroiwai & small & 1 & 4 & $1 / 2+4+1 / 2$ & to anterior to middle XIV & bulbous & XVI to XVIII & developed, ovate \\
\hline O. meisai & middle & 1 & 4 & $5+1 / 4$ & to posterior XV & rudimentary tubular & absent & absent \\
\hline O. naraharaetmagarum & small & 1 & 4 & $1 / 2+4+1 / 2$ & to posterior XIII & bulbous & $\mathrm{XV}$ to $\mathrm{XX}$ & developed, ovate \\
\hline O. tsushimensis & middle & 1 & 4 & $1 / 2+5$ & to posterior XIII to posterior XIV & bulbous & XVII to XIX & developed, ovate \\
\hline O. whitmani & middle & 1 or 2 & 4 & $1 / 2+4+1 / 2$ & to anterior to posterior XIV & bulbous & XVI to XVIII & developed, ovate \\
\hline
\end{tabular}


419

420

421

422

423

424

425

426

427

428

429

430

431

432

433

434

Figure captions

Figure 1. Orobdella ghilarovi sp. nov., holotype, KUZ Z2068. (a) Dorsal view. (b) Ventral View. (c) Dorsal view of live animal. Scale bars, $5 \mathrm{~mm}$.

Figure 2. Orobdella ghilarovi sp. nov., holotype, KUZ Z2068. (a) Dorsal view of somites I-

VIII. (b) Ventral view of somites I-VIII. (c) Dorsal view of somites XXIV-XXVII and caudal sucker. (d) Ventral view of somites XXIV-XXVI and caudal sucker. (e) Ventral view of somites X-XIII. (f) Ventral view of gastropore and female gonopore. Abbreviations: af, annular furrow; an, anus; cl, clitellum; fg, female gonopore; gp, gastropore; mg, male gonopore; np, nephridiopore. Scale bars, $2 \mathrm{~mm}$ (a-e); $0.2 \mathrm{~mm}$ (f).

Figure 3. Orobdella ghilarovi sp. nov., holotype, KUZ Z2068. (a) Ventral view of gastroporal duct. (b) Ventral view of junction between crop and intestine with intestinal caeca. (c) Dorsal view of reproductive system including ventral nervous system. (d) Dorsal view of male atrium including position of ganglion XI. (e) Left lateral view of male atrium. (f) Ventral view of male atrium. (g) Dorsal view of female reproductive system including position of ganglion XIII. Abbreviations: ac, atrial cornua; at, atrium; cod, common oviduct; cp, crop; ed, ejaculatory duct; ep, epididymis; gd, gastroporal duct; gp, gastropore; ic, intestinal caecum; 
438 in, intestine; od, oviduct; ov, ovisac; ph, pharynx. Scale bars, $2 \mathrm{~mm}$ (a, b); 5 mm (c); $0.5 \mathrm{~mm}$ 439 (d-g).

440

441 Figure 4. Bayesian inference tree for 8084 bp of nuclear 18S rRNA, 28S rRNA and histone

442 H3 plus mitochondrial COI, tRNA ${ }^{\text {Cys }}$, tRNA ${ }^{\text {Met }}, 12 S$ rRNA, tRNA ${ }^{\text {Val }}$, 16S rRNA, tRNA ${ }^{\text {Leu }}$ and

443 ND1 markers. Inset shows real branch lengths. Numbers on nodes represent bootstrap values

444 for maximum likelihood and Bayesian posterior probabilities.

445 


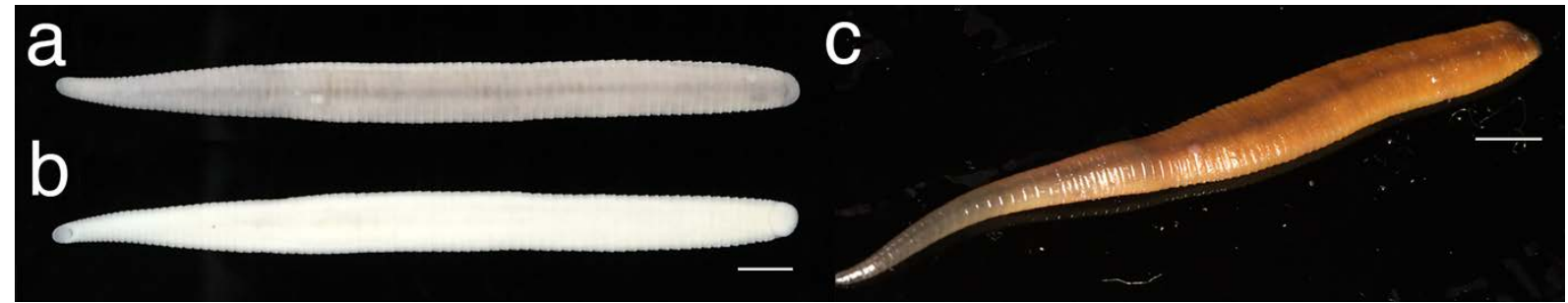

447 Figure 1. Orobdella ghilarovi sp. nov., holotype, KUZ Z2068. (a) Dorsal view. (b) Ventral View. 448 (c) Dorsal view of live animal. Scale bars, $5 \mathrm{~mm}$. 

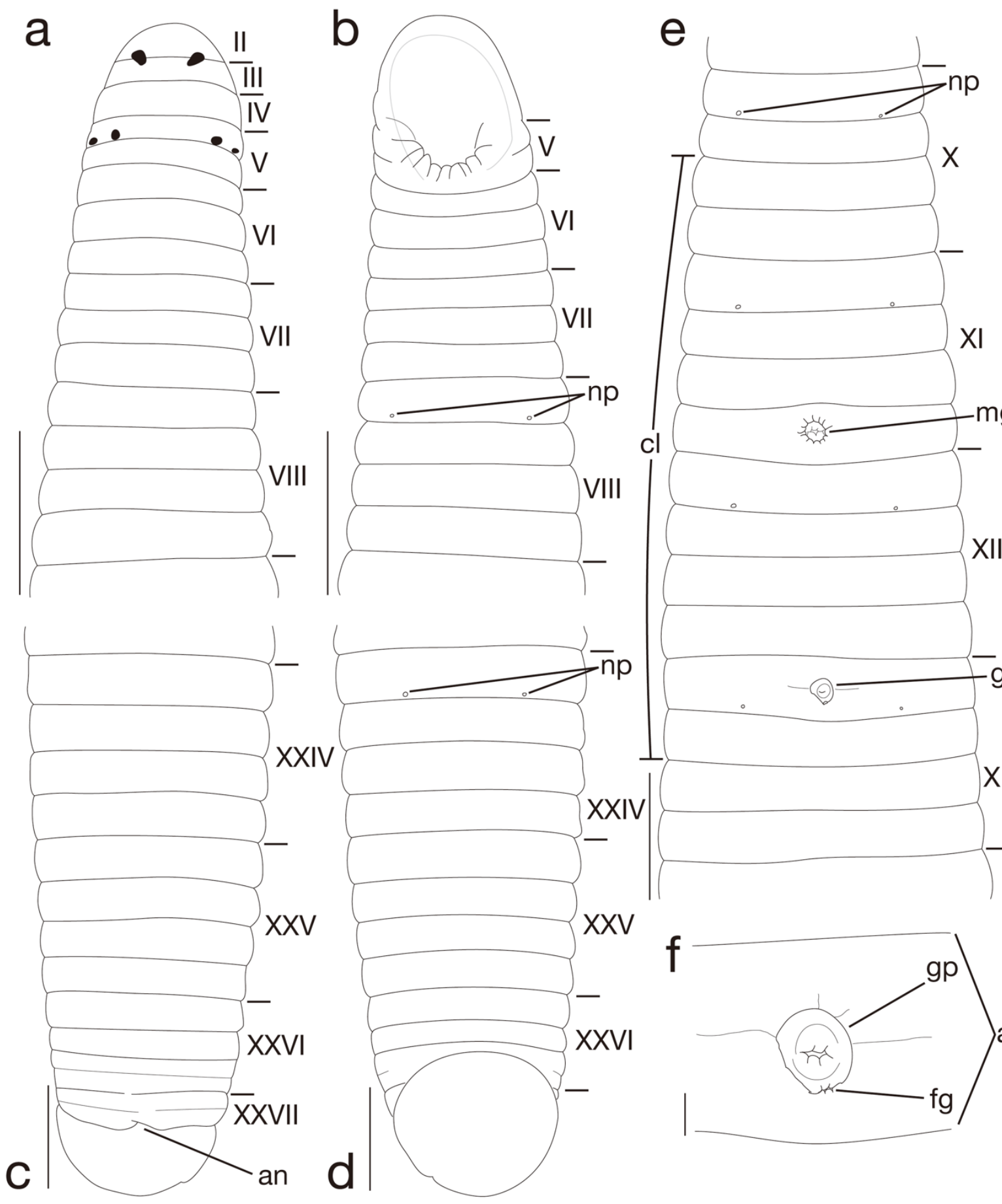

$\mathrm{cl}$

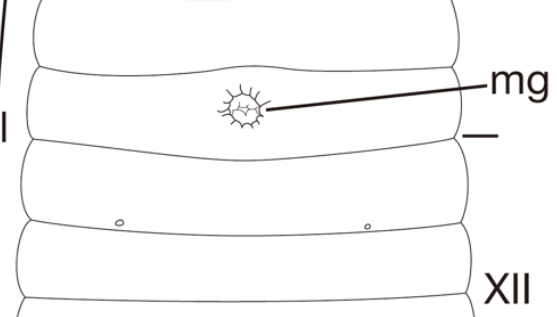

Figure 2. Orobdella ghilarovi sp. nov., holotype, KUZ Z2068. (a) Dorsal view of somites IVIII. (b) Ventral view of somites I-VIII. (c) Dorsal view of somites XXIV-XXVII and caudal sucker. (d) Ventral view of somites XXIV-XXVI and caudal sucker. (e) Ventral view of somites $\mathrm{X}$-XIII. (f) Ventral view of gastropore and female gonopore. Abbreviations: af, annular furrow; an, anus; cl, clitellum; fg, female gonopore; gp, gastropore; mg, male gonopore; np, nephridiopore. Scale bars, 2 mm (a-e); 0.2 mm (f). 

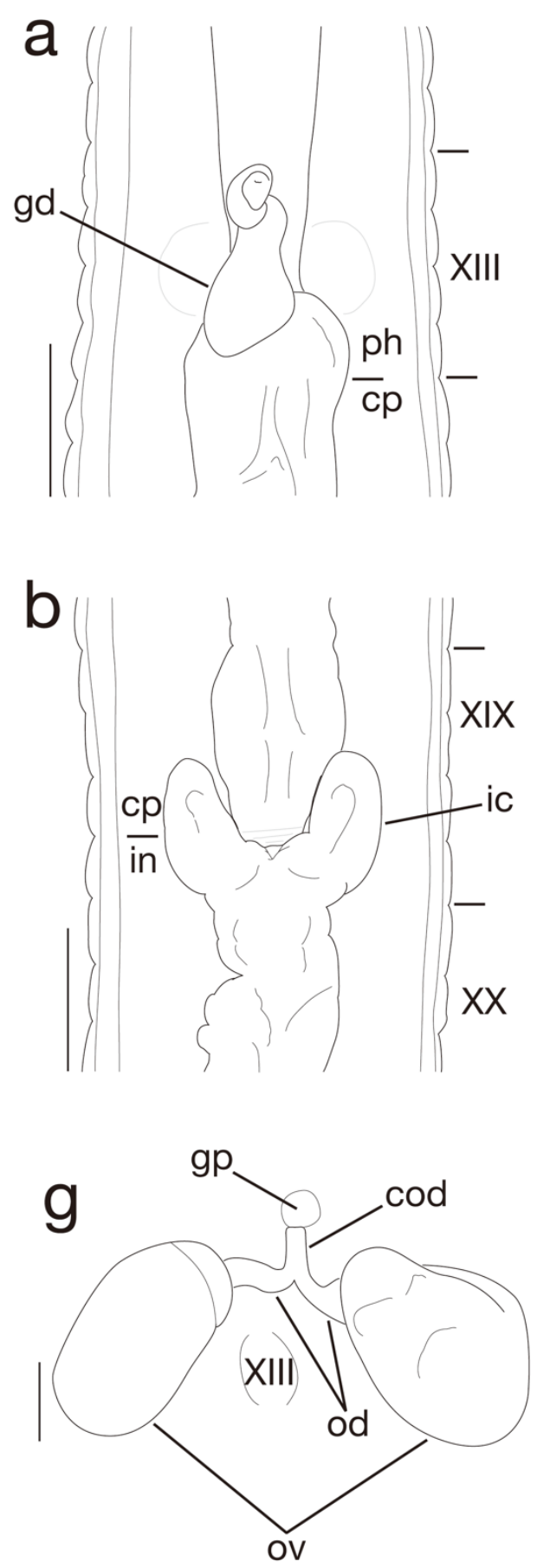

Figure 3. Orobdella ghilarovi sp. nov., holotype, KUZ Z2068. (a) Ventral view of gastroporal

460 duct. (b) Ventral view of junction between crop and intestine with intestinal caeca. (c) Dorsal view of reproductive system including ventral nervous system. (d) Dorsal view of male atrium including position of ganglion XI. (e) Left lateral view of male atrium. (f) Ventral view of male atrium. (g) Dorsal view of female reproductive system including position of ganglion XIII. Abbreviations: ac, atrial cornua; at, atrium; cod, common oviduct; cp, crop; ed, ejaculatory 
465 duct; ep, epididymis; gd, gastroporal duct; gp, gastropore; ic, intestinal caecum; in, intestine;

466 od, oviduct; ov, ovisac; ph, pharynx. Scale bars, 2 mm (a, b); 5 mm (c); 0.5 mm (d-g). 


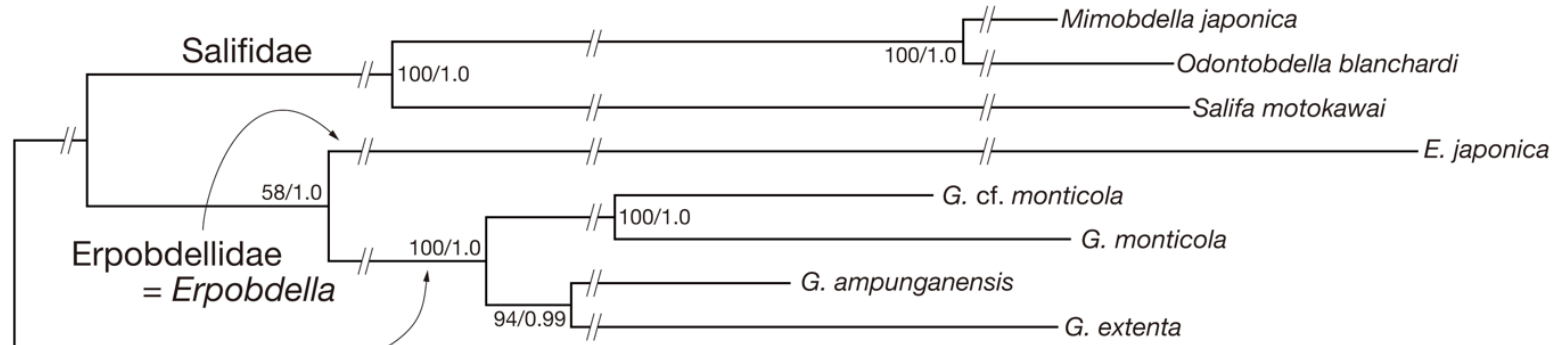

Gastrostomobdellidae

= Gastrostomobdella

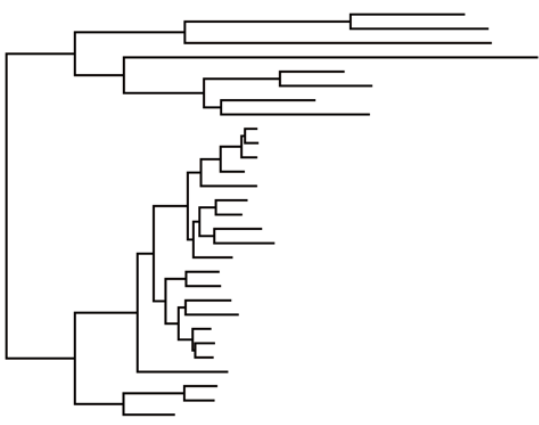

$100 / 1.0$

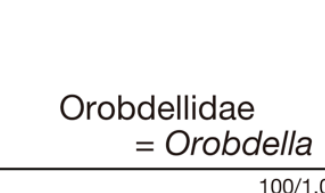

Figure 4. Bayesian inference tree for 8084 bp of nuclear 18S rRNA, 28S rRNA and histone H3 plus mitochondrial COI, tRNA ${ }^{\text {Cys }}$, tRNA ${ }^{\text {Met }}$, 12S rRNA, tRNA ${ }^{\text {Val }}, 16 S$ rRNA, tRNA ${ }^{\text {Leu }}$ and ND1 markers. Inset shows real branch lengths. Numbers on nodes represent bootstrap values for maximum likelihood and Bayesian posterior probabilities. 